Received: 20.4.2011 Corrected: 5.12.2011.

Accepted: 24.1.2012

Available online: 15.2.2012.

\title{
Seasonal Occurrence of Maximum Annual Flows in the Danube River Basin in Croatia
}

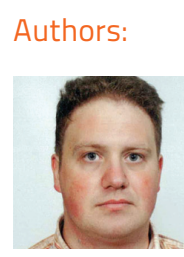

Darko Barbalić, B.Sc. (Civ.Eng.)

Hrvatske vode

darkob@voda.hr

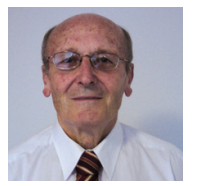

Prof. Josip Petraš, Ph.D. (Civ.Eng.)

University of Zagreb

Faculty of Civil Engineering

jpetras@grad.hr
Professional paper

\section{Darko Barbalić, Josip Petraš}

\section{Seasonal Occurrence of Maximum Annual Flows in the Danube River Basin in Croatia}

The analysis of seasonal occurrence of maximum annual flows, conducted at 95 gauging stations within the Danube river basin, is presented. Burn's vector method, and RVA - Range of Variability Approach method based on elementary statistical analysis of maximum annual flow dates, are used. The analysis shows that the lowest seasonal variability of maximum flows occurs in Gorski Kotar drainage basins, and that this maximum statistically occurs near the end of the year. The seasonal variability of maximum annual flows is much higher for other gauging stations included in the analysis

\section{Key words:}

maximum annual flows, seasonal occurrence, Danube River basin, Burn's vector, RVA - Range of Variability Approach

Stručni rad

Darko Barbalić, Josip Petraš

\section{Sezonska pojavnost velikih voda na slivu Dunava u Hrvatskoj}

U radu je provedena analiza sezonske pojavnosti velikih voda za 95 hidroloških postaja na slivu rijeke Dunav. Korištene su metoda Burnova vektora te metoda RVA - Range of Variability Approach koja se zasniva na proračunu osnovnih statistika datuma pojave maksimalnog protoka. Analiza je pokazala najveću vremensku ustaljenost pojave maksimalnih protoka na slivovima Gorskog kotara, pri čemu je statistički očekivano vrijeme njihove pojave kraj godine. Ostale analizirane postaje imaju znatno manju vremensku ustaljenost pojave godišnjih maksimuma.

Ključne riječi:

velike vode, sezonska pojavnost, sliv rijeke Dunav, Burnov vektor, RVA - Range of Variability Approach

Facbericht

Darko Barbalić, Josip Petraš

\section{Saisonale Hochwasser im Donauflussgebiet in Kroatien}

In der Arbeit wurde die Analyse der saisonalen Erscheinung von Hochwasser an 95 hydrologischen Messstellen im Donauflussgebiet durchgeführt. Es wurden die BurnVektor-Methode und die RVA - Range of Variability Approach - Methode angewandt, die auf der Berechnung von grundlegenden Statistiken von Tagen, an denen ein maximaler Durchfluss vorhanden ist, begründet. Die Analyse hat die größte Zeitspanne von maximalen Durchflüssen in den Flussgebieten von Gorski kotar ergeben, wobei statistisch gesehen diese zu Jahresende zu verzeichnen ist. Die übrigen analysierten Pegel weisen bedeutend kleinere Zeitspannen der Erscheinung der Jahresmaxima auf. 


\section{Introduction}

The EU Water Framework Directive [1], and the EU Directive on the Assessment and Management of Flood Risks [2] have introduced a number of novelties that are now being gradually implemented into the Croatian water management practice. The key planning documents required by the above-mentioned directives are River Basin Management Plans and Flood Risk Management Plans. The preparation of river basin management plans, and preliminary analysis of flood risks, have inter alia revealed the need for preparation of uniform, consistent and reliable hydrological base of regional character.

Unlike most of the standard hydrological analyses that are regularly conducted in Croatia, the analyses of seasonal occurrence of hydrological extremes are not so frequent, although the knowledge of their results is not without significance.

According to $[3,4,5,6]$, the knowledge of high water regime is highly applicable and useful in hydrology and water management. In general terms, seasonal occurrence is considered to be an excellent indicator for understanding genesis of high flows and flooding patterns. It is used in the analysis of seasonal probability for differentiation of floods that have been caused by various atmospheric factors. This parameter is particularly useful in various regional flood analyses or, more broadly, for grouping hydrological areas into homogenous regions. In addition, it has been clear for a long time that the needs of aquatic ecosystems can not be met solely by provision of biological minimum and that, to ensure optimal existence of such ecosystems, great attention should be paid to various water regime aspects, including floods and patterns of their seasonal occurrence. In fact, one can find in literature many examples pointing to high significance of seasonal extremes. For instance, according to [7], the occurrence of hydrological extremes can influence the start of spawning of migratory fish species greatly, according to [8], the temperature of soil (which is season-dependent) during the floods plays a significant role in the denitrification processes in wetlands and so forth.

The above considerations show that an appropriate attention must be given to the analysis of seasonal occurrence of floods, and that the applicability of results is dependent on a number of factors that can not be predicted in advance. One of benefits will certainly be an answer to the question whether a firm seasonal pattern of high flow occurrences is in fact detected for a given region. If there is a strong seasonality of floods, then it can be expected with a high level of probability that water and waterdependent ecosystems are reasonably sensible to such patterns, and that change in the seasonality of floods could adversely affect their well-being. For that reason, in addition to maintaining appropriate quantities of water, it is also necessary to maintain an appropriate seasonality, frequency and duration of floods, in order to achieve a good ecological status of water ecosystems. Published works on seasonal occurrence of extreme flows are far from rare, so relevant papers are currently available for Germany [5], Austria, Switzerland, Slovakia and Romania [9], parts of Greece [6], and for other countries and regions.

The analysis conducted in the scope of this paper is the first step in the study of seasonal occurrences of hydrological phenomena within the Danube river basin in Croatia [8].

\section{General description of methods used}

The analysis of seasonal occurrence of maximum annual flows was conducted using two methods that are often used in practical applications.

\subsection{Burn's vector method}

One of the methods that is frequently used for estimating seasonal occurrence of extreme events is the Burn's vector method. This method describes variability of the date at which the maximum annual flow occurs in such a way that the direction of the vector corresponds to the expected occurrence date within a year, while the vector length describes variability around the expected occurrence date [10].

The Burn's vector (expressions taken from $[6,9]$ ) is calculated by, at first, determining the orientation (direction) of the unit vector of the date the maximum annual flow has occurred for each year:

$\theta_{i}=D_{i} \frac{2 \pi}{365}$

where:

$\theta_{i} \quad$ - "orientation" of that date in year on which the maximum annual flow has occurred (rad)

$n$ - ordinal number of year in a time series (from 1 to $n$ )

$i \quad$ - total number of years in the time series

$D_{i}$ - ordinal number of the date in year $i$ on which the maximum annual flow has occurred $(0-365)$

The abscissa $\bar{x}$ and ordinate $\bar{y}$ of the Burn's vector are calculated as follows:

$\bar{x}=\frac{1}{n} \sum_{i=1}^{n} \cos \theta_{i}$

$\bar{y}=\frac{1}{n} \sum_{i=1}^{n} \sin \theta_{i}$

where:

from which the orientation of the Burn's vector $\bar{\theta}$ can be derived:

$\bar{\theta}=\operatorname{arctg}\left(\frac{\bar{y}}{\bar{x}}\right)$ 
and its intensity $r$ is:

$r=\sqrt{\bar{x}^{2}+\bar{y}^{2}}$

The orientation $\bar{\theta}$ of the Burn's vector can have a value from 0 (which corresponds to the expected occurrence of an annual extreme on $1^{\text {st }}$ of January in the morning), to $2 \pi$ (which corresponds to the expected occurrence of an annual extreme on $31^{\text {st }}$ of December in the evening). The Burn's vector orientation can be used to calculate a given date using the expression (1). The Burn's vector intensity $r$ can have a value between 0 and 1 , where it is equal to 1 if an extreme event has occurred every year on the same date, while it move towards zero if extreme occurrences are uniformly distributed during the year. However, in case extreme occurrences are approximately uniformly distributed during the year then, due to small vector intensity, its orientation can change significantly due to small changes in input data.

The Burn's vector is presented in the so called Burn's diagram which enables easier visualisation of results, especially if results for several stations are displayed at the same time. An example of the Burn's diagram and the Burn's vector structure for the gauging station for which the expected occurrence of annual maximum falls on $31^{\text {st }}$ of October $\left(\boldsymbol{\theta}=5.22 \mathrm{rad}=299^{\circ}, r=0.601\right)$ is shown in Figure 1.

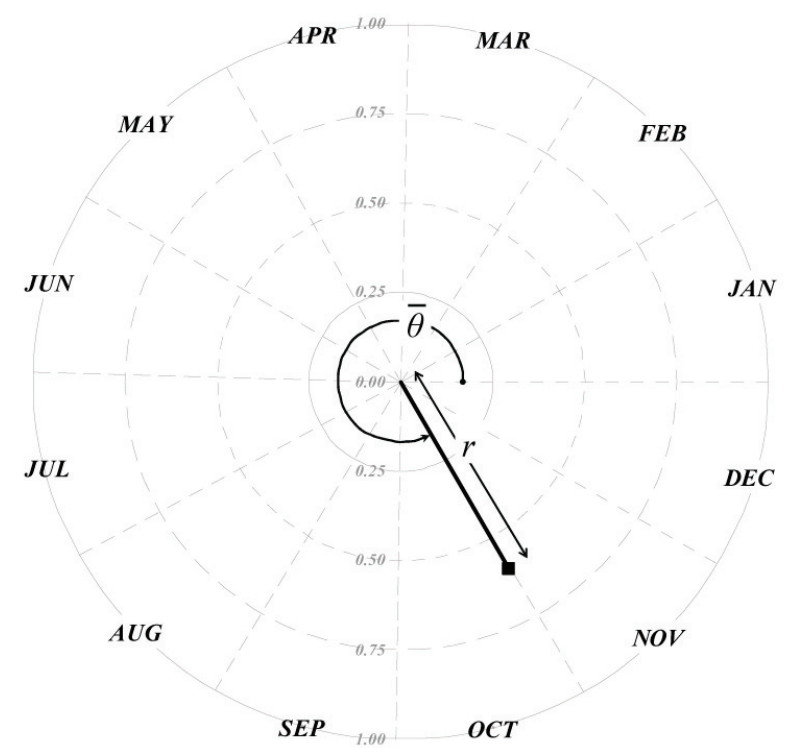

Figure 1. Example of a Burn's diagram

\subsection{Range of Variability Approach method}

The second method to analyze seasonal occurrence is to calculate the mean value $(\bar{D})$ and standard deviation $(S D)$ of the ordinal number of the date of annual maximum flow, counting from the start of the year, as defined in the method "Range of Variability Approach" (RVA) described in [11]. A useful property of this method is that the variation of an occurrence is described by standard deviation, which is a well known statistical parameter with clear meaning, unlike the Burn's vector intensity which points less clearly to the variation of an occurrence. On the other hand, direct application of this method can easily lead to erroneous conclusions. In fact, floods occur most often in Croatia either in the beginning or at the end of the calendar year. If such a series of maximum annual flow dates is formed with respect to $1^{\text {st }}$ of January, the members of the series (ranks) which are being analyzed have either very small values (January and February), or very high values (November and December). Thus the calculation results in a mean value that is close to the middle of the year (when in fact high floods are least likely to occur in Croatia), and the standard deviation is high. Using an appropriate "design" year, i.e. by moving the date of the start of the year for a certain number of months, a more reliable result is obtained in the analysis. In order to calculate these values, standard expression for the mean value (6) and standard deviation (7) is used:

$\bar{D}=\frac{1}{n} \sum_{i=1}^{n} D_{i}$

$S D=\sqrt{\frac{\sum_{i=1}^{n}\left(D_{i}-\bar{D}\right)^{2}}{n-1}}$,

where:

$\bar{D} \quad$ - mean value of the ordinal number of the day in a "design" year when a maximum has occurred

$n \quad$ - number of years in the series

$i$ - ordinal number of the year in the series ( 1 to $n$ ),

$D_{i}$ - ordinal number of that day in the "design" year $i$ when a maximum annual flow has occurred (0 to 365)

$S D$ - standard deviation (days)

The minimum value of the standard deviation can be equal to 0 if the maximum annual flow occurs each year on the same date. If maximum annual flow occurrences are uniformly distributed along the year, then the standard deviation value equals to approximately 106, and the occurrence date corresponds to the mean date in the "design" year ( $2^{\text {nd }}$ of July in case of a calendar year).

Due to its trigonometric form, the Burn's vector is much less sensitive to the date of start of the "design" year, although it should be noted that due to change of the beginning date of the "design" year, the change also occurs in the order of extreme flows, and hence in the order of dates of their occurrence.

Taking all this into account, and in order to obtain results as reliable as possible that enable comparison of methods, the calculation was made in accordance with the RVA method using "design" years. At that, a specific start of "design" year was 
determined for each gauging station. This was done in such a way that the start of "design" year was selected by choosing the beginning of that month for which the standard deviation of the resulting set of dates would be the smallest. It should be noted that all dates that are the result of the analysis are given with respect to a calendar year.

\section{Occurrence Calculated of Maximum Annual Flows}

\subsection{Input data}

The total of 95 gauging stations, situated in the Danube river basin in Croatia, were selected for this analysis so that each set of maximum annual flow dates had 20 members or more. The total of 17 stations were selected in the Drava river basin and in the Danube's direct drainage area in Croatia, and this on the following rivers: Danube (2 stations), Drava (4 stations), Mura (2 stations), Bednja (3 stations), and one station on each of the following watercourses: Trnava, Gliboki, Koprivnica, Komarnica, Voćinka and Vojlovica.

In the Sava river basin (excluding Kupa subbasin), 32 stations were selected on the rivers of Sava (12 stations), Sutla (2 stations), Krapina (2 stations), Vrapčak (2 stations), Lonja (2 stations), Česma (2 stations), and one station on each of the following watercourses: Bregana, Lipovačka and Rudarska Gradna, Črnomerec, Bijela, Una, Šumetlica, Ilova, Orljava and Londa.

In the Kupa river subbasin, 46 stations were selected on the rivers of Kupa (12 stations), Gornja Dobra (3 stations), Donja Dobra (3 stations), Korana (5 stations), Glina (3 stations) and one station on each of the following watercourses: Čabranka, Kupica, Kupčina, Križ Potok, Vela and Bela Voda, Leska, Klada, Vitunjčica, Ribnjak, Globornica, Donja Mrežnica, Tounjčica, Kozjak, Matica, Slunjčica i Radonja.

An average time span of time series included in analysis is 48 years. For the most of the stations, calculated beginning of "design" year was during summer months (Figure 2).

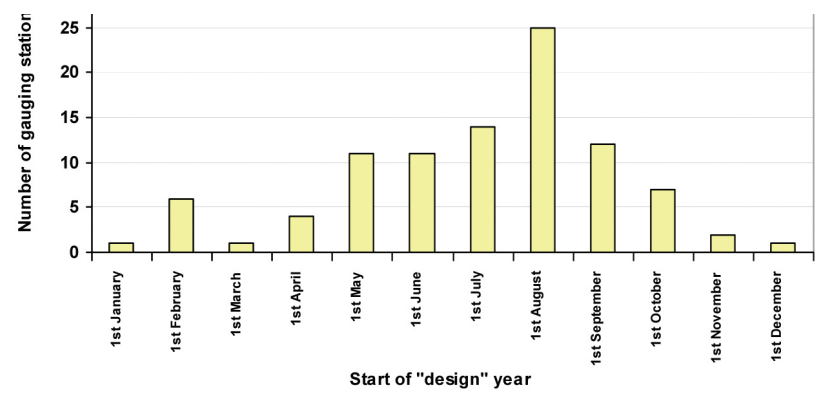

Figure 2. Number of analyzed stations with appropriate "design" year start

\subsection{Calculation results}

As could have been expected, the results obtained by both methods show that the expected maximum annual flows occur during the winter months (November - February) for almost three fourths of the analyzed stations, (Figure 3).

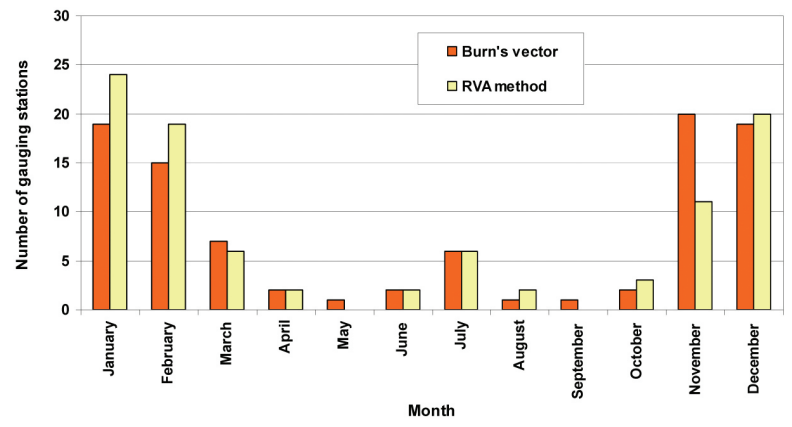

Figure 3. Number of analyzed stations and expected months of maximum annual flows occurrence

As a result of snow regime of the Danube, Drava and Mura rivers, high flows occur on these rivers in summer season, i.e. in June and July, which clearly differentiates them from other watercourses subjected to this analysis.

The occurrence of extreme flows near the end of calendar year is typical for a smaller western part of the studied area, greatly influenced by karst, which includes Gorski Kotar with the Gornja Dobra river and Kupa river upstream from the Dobra river mouth. In this area, the seasonal variability of occurrence of maximum annual floods is the lowest.

In the eastern part of the Danube river basin in Croatia (with the exception of the Danube, Drava and Mura rivers), maximal annual flows mostly occur in the first quarter of the year, and here the seasonal variability of maximal annual flow occurrences is relatively high.

Although small watersheds around city of Zagreb have high seasonal variability of high flows, it can generally be stated that they occur in the middle of the year, which is quite logical as their floods are mostly result of intensive local rainfalls.

The Burn's diagram and cartographic view of seasonal occurrence of maximum annual flows are presented in Figures 4 and 5.

The standard deviation of maximum annual flow occurrences varies from 70 to 90 days (Figure 6) on more than $60 \%$ of stations under study. The distribution of the Burn's vector intensities is presented in Figure 7.

A comparatively high standard deviation of occurrences of annual maximum flow, ranging from 50 to 100 days (Figure 6), and relatively small intensities of the Burn's vector (Figure 7) point to the lack of seasonal regularity of annual maximum flows in the studied area, as determined by both methods. As two methods were used, a certain deviation of their results can also be expected. 


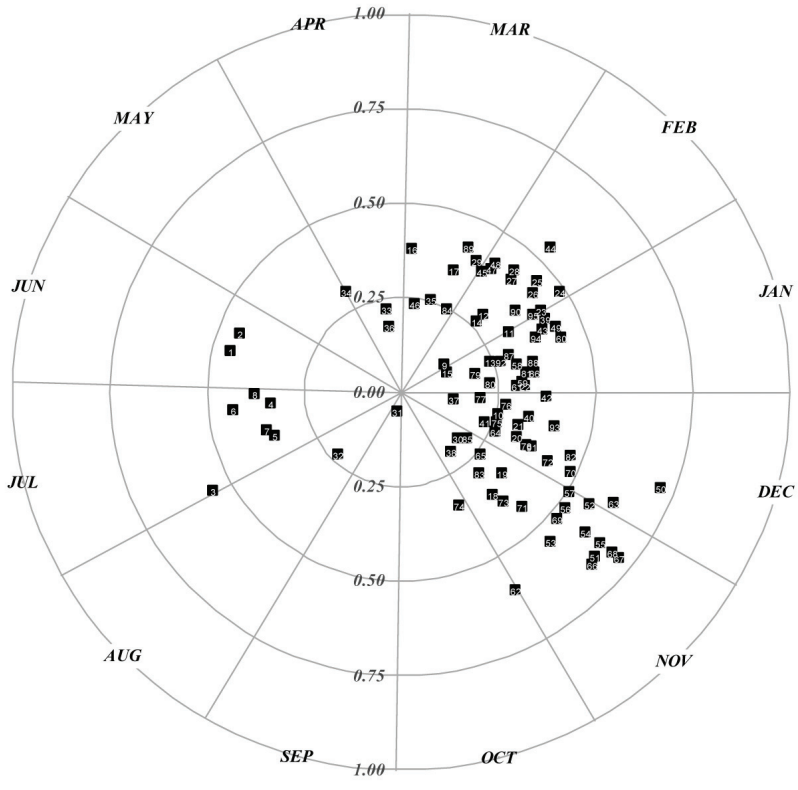

Figure 4. Burn's diagram of gauging stations under study

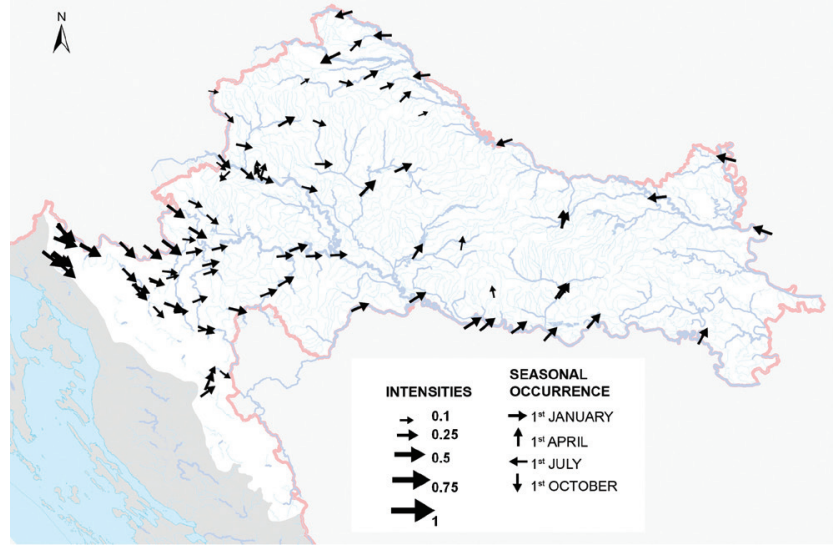

Figure 5. Cartographic view of seasonal occurrence of maximum annual flows, after the Burn's vector

Thus differences in the expected maximum annual flow date calculated via these two methods are sometimes quite evident (Figure 8). However, on one third of the stations, this difference is less than 5 days, and on more than one half of the stations the difference is less than 10 days. Considering high standard deviation of the order of 50 - 100 days (Figure 6), and small Burn's vector intensities (Figure 7), the difference in expected extreme dates is in the most cases not significant for practical applications.

It can be seen from Figure 9 that the mentioned differences between the two methods, as to expected maximum annual flows occurrence dates, are greater in case of stations where seasonality is less strong, i.e. in case of those stations where the occurrence of extremes is distributed more uniformly throughout the whole year. This conclusion also coincides with theoretical study of the methods, which in case of strong seasonality of phenomena under study provide similar results (same expected maximum

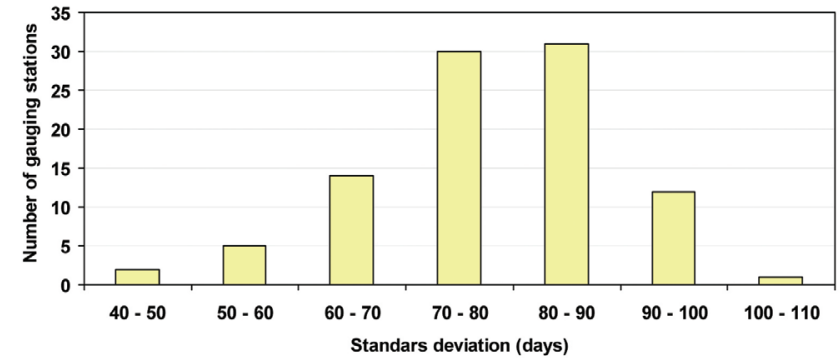

Figure 6. Distribution of standard deviations of maximum annual flows occurrence from the expected date (RVA method)

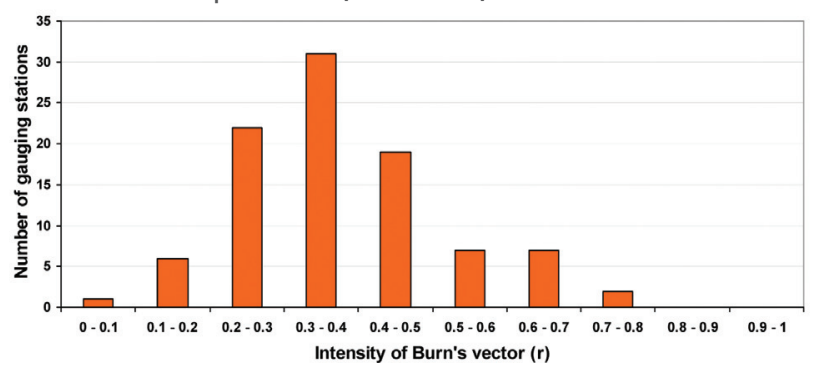

Figure 7. Distribution of Burn's vector intensities

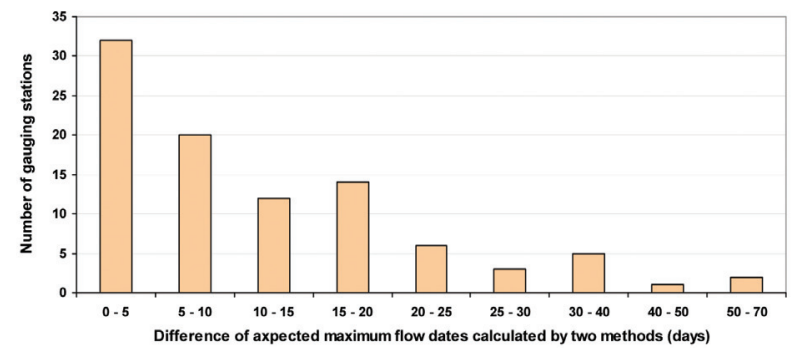

Figure 8. Difference between the two methods as to expected maximum flow dates

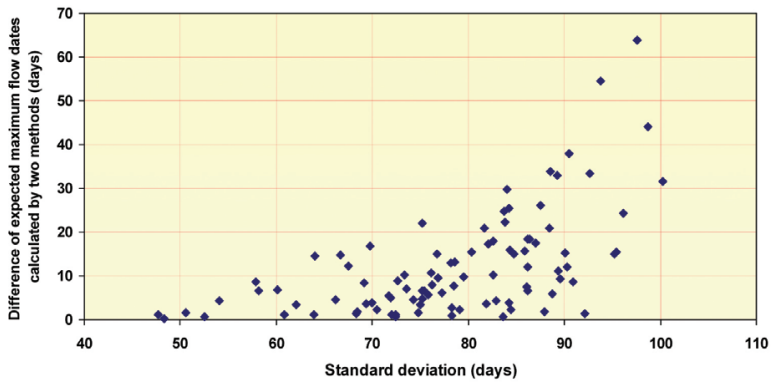

Figure 9. Differences in expected maximum flow dates as determined according two methods used in the study

annual flow occurrence date). In case the phenomena are uniformly distributed over time, small differences in input data may significantly influence orientation of the vector (i.e. expected date of occurrence), due to small Burn's vector intensities. In the same case, the expected date of occurrence, defined according to RVA, tends to be situated somewhere in the middle of the year. That is why significant differences in results are possible and even highly probable. The Burn's vector intensity, and standard deviation according to RVA method, are both used to measure variability of occurrence of maximum annual flows 
as related to the expected date in a year. By analyzing equations of both methods, itcan beestablished thatthe $r \approx 1$ and $S D \approx 0$ is valid in case of strong seasonality of extremes. Furthermore, $r \approx 0$ and $S D \approx 106$ days is valid for extremes that are uniformly distributed in time. The comparison of calculated values $r$ and $S D$ is presented in Figure 10. The Figure shows that a very strong link exists between the parameters $r$ and $S D$, and that there is a very good correspondence with the previously indicated theoretical characteristics of methods used in this study.

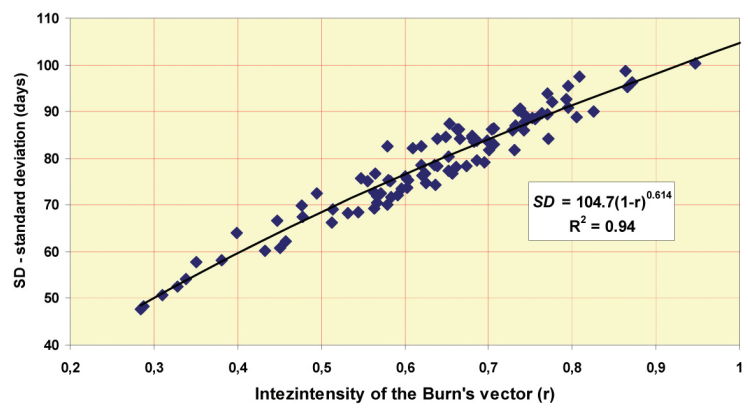

Figure 10. Relationship between the Burn's vector intensities and the standard deviation according to RVA method

\section{Conclusions}

Results obtained by preliminary analysis of seasonal occurrence of maximum annual flows in the Danube river basin in Croatia have revealed some interesting patterns. It should however be emphasized that these patterns are not so strong as, for instance, those registered for the mountainous parts of southern Austria and Switzerland (Alps) where the intensity of the Burn's index often exceeds 0.8. The situation in Croatia can better be compared to flatland drainage areas of Austria and Switzerland, and to Slovakia and Romania. To enable a more complete understanding of the genesis of high flows it would inter alia be highly advisable to conduct a similar analysis for extreme rainfalls. The comparison of methods has shown that they result in similar expected dates $(\bar{\theta}$ and $\bar{D})$ for seasonally regular occurrences, and that differences in results become higher with an increase in dispersion of extremes over the year. It can however be seen that there is a very strong correlation between parameters for measuring seasonal variability of both methods ( $r$ and $S D$ ) in the Danube river basin in Croatia.As one of the reasons for preparation of this study was to establish a hydrological base for assessing the need to introduce seasonal occurrence of high flows, as an indicator of hydrological alterations of water according to EU Water Framework Directive (where the status stands for ecological status), it would be difficult to make final and firm conclusions without realization of extensive further biological studies. Nevertheless, the results obtained have shown that the introduction of seasonal occurrence of high flows as an indicator of hydrological alteration of water status (according to the Water Framework Directive) would be most appropriate in the upper drainage areas of Kupa and Dobra rivers where seasonality of high flows is the strongest.

In other areas the seasonal occurrence is much less expressed and so it can be assumed that these ecosystems are less sensitive to changes in the time of occurrence of high flows. In addition, considering a relatively high standard deviation with respect to expected date of occurrence, amounting to 50 days or more, the adjustment to this condition should not be a significant problem for water users.

The analysis has revealed that in study area the seasonality of high flows should be calculated by means of "design" years, so that a more reliable information is obtained. It would certainly be advisable to further continue the analysis of seasonal occurrence patterns and not only for high flows, but also for other components of the water regime, low flows in particular.

\section{REFERENCES}

[1] Okvirna direktiva o vodama Europske unije, Vodnogospodarska osnova Hrvatske, izdanja II, Hrvatske vode, Zagreb, 2002.

[2] Directive 2007/60/EC of the European Parliament and of the Council of 23 October 2007 on the Assessment and Management of Flood Risks, Official Journal of the European Union L 288/27.

[3] Merz, R.; Piock-Ellena, U.; Bloschl, G.; Gutknecht, D.: Seasonality of flood processes in Austria, Hydroiogical Extremes: Understanding, Predicting, Mitigating (Proceedings of IUGG 99 Symposium HSI, Birmingham, July 1999, IAHS Publication no 255, 1999.

[4] Uhlenbrook, S.; Steinbrich, A.; Tetzlaff, A.; Leibundgut, C.: Regional analysis of the generation of extreme floods, Fourth International FRIEND Conference, IAHS Publication no. 274, 2002.

[5] Beurton, S.; Thieken, A.H.: Seasonality of Floods in Germany. Hydrological Sciences Journal 54 (1), 62-76, 2009.

[6] Koutroulis, A. G.; Tsanis, I. K.; Daliakopoulos, I. N.: Seasonality of floods and their hydrometeorologic characteristics in the island of Crete, Journal of Hydrology, (2010), doi:10.1016/j.jhydrol.2010.04.025

[7] Swanson S: Indicators of Hydrologic Alteration, Resource Notes No 58, National Science \& Technology Center, Bureau of Land Management, SAD, 2002.

[8] Hernandez, M. E.; Mitsch, W. J.: Denitrification in created riverine wetlands, Influence of hydrology and season, Ecological Engineering 30, 78-88, 2007.

[9] Parajka J. et al: Seasonal characteristics of flood regimes across the Alpine-Carpathian range. Journal of Hydrol. (2010), doi:10.1016/j. jhydrol.2010.05.015

[10] De Michele, C.; Rosso, R.: A multi-level approach to flood frequency regionalisation, Hydrology and Earth System Sciences, 6(2), 185194, 2002.

[11] Richter, B.; Baumgartner, J.; Wigington, R.; Braun P.: How much water does a river need?, Freshwater Biology 37, 231-249, 1997. 